\title{
BIPOLAR VERSUS MONOPOLAR TRANSURETHRAL RESECTION OF PROSTATE IN TREATMENT OF BENIGN PROSTATIC ENLARGEMENT
}

\author{
Niraj Thapa ${ }^{1 *}$, Ganesh Bhakta Acharya ${ }^{2}$, Abhishek Poudel $^{3}$, Ananda Neupane $^{3}$, Sushil Mishra ${ }^{3}$
}

\begin{abstract}
Affiliation
1. Lecturer, Department of Urosurgery, Manipal College of Medical Sciences, Nepal

2. Lecturer, Department of Urosurgery, Manipal College of Medical Sciences, Nepal

3. Resident, Department of Surgery, Manipal College of Medical Sciences, Nepal
\end{abstract}

\section{ARTICLE INFO}

Received : 25 November, 2021

Accepted : 15 January, 2022

Published : 21 Februrary, 2022

(c) Authors retain copyright and grant the journal right of first publication with the work simultaneously licensed under Creative Commons Attribution License CC - BY 4.0 that allows others to share the work with an acknowledgment of the work's authorship and initial publication in this journal.

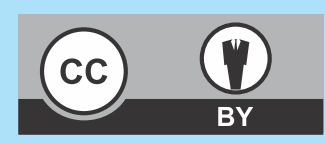

ORA 285

DOI: https://doi.org/10.3126/bjhs.v6i3.43215

\author{
* Corresponding Author \\ Dr. Niraj Thapa \\ Lecturer \\ Department of Urosurgery \\ Manipal College of Medical Sciences, Nepal \\ Email: niraj94@live.com \\ ORCID: https://orcid.org/0000-0002-1549-2314
}

\section{Citation}

Bipolar Versus Monopolar Transurethral Resection of Prostate in Treatment of Benign Prostatic Enlargement. Niraj Thapa, Ganesh Bhakta Acharya, Abhishek Poudel, Ananda Neupane, Sushil Mishra. BJHS 2021;6(3)16.1647-1651.

\section{ABSTRACT}

\section{Introduction}

Bipolar transurethral resection (B-TURP) is an effective modality for surgery of Benign Prostatic Obstruction, and has been widely studied for its efficacy and safety against the well-established method; Monopolar Transurethral resection (M-TURP).

\section{Objectives}

The study aimed to assess the feasibility of B-TURP over MTURP in terms of hospital stay, resection time, resected tissue volume, changes in hemoglobin and sodium, blood transfusion required, complications like TUR syndrome, clot retention and hemorrhagic episodes.

\section{Methodology}

An analytical study was done in cases who underwent TURP from August 2018 to August 2020. Parameters like hospital stay, resection time, resected tissue volume, changes in hemoglobin and sodium, blood transfusion required, complications like TUR syndrome, clot retention and hemorrhagic episodes were comparedin between B-TURP and M-TURP. Statistical analysis was done using SPSS 22.0 software.

\section{Results}

Seventy-three patients were compared in this study; 33 had undergone B-TURP and 40 patients had undergone $\mathrm{M}$ TURP.Total hospital stay was slightly lesser in B-TURP. The post-operative $\mathrm{Hb}$ in M-TURP was significantly lesser than $\mathrm{B}$ TURP (11.10 \pm 1.321 vs $12.24 \pm 1.225, P<0.001)$. Although the drop in hemoglobin was statistically significant in both the groups, the hemoglobin drop was slightly lesser in B-TURP. The mean difference in pre and post-operative hemoglobin was 1.148 in M-TURP and 0.181 in B-TURP. TUR syndrome was significantly higher in M-TURP (6,8.2\%vs0, $0 \%$; $P=0.029)$. There was no significant difference in between resection time, post-operative sodium, post-operative hemorrhagic episodes, clot retention and blood transfusions.

\section{Conclusion}

Bipolar TURP is safe and effective for transurethral resection of prostate with relative shorter hospital stay, lesser bleeding and TUR syndrome in comparison to Monopolar TURP.

\section{KEY WORDS}

Benign Prostatic Hyperplasia (BPH), Lower Urinary Tract Symptoms (LUTS), Transurethral Resection of Prostate (TURP) 


\section{INTRODUCTION}

Benign prostatic Enlargement (BPE) is one of the most common diseases that affect aging males. ${ }^{1,2}$ The lower urinary tract symptoms (LUTS) due to benign prostatic obstruction (BPO) continue to be a major concern, affecting about a third of men over age $50 .^{3,4}$ It has been estimated that approximately $30 \%$ of male population in Europe and United States have a chance of undergoing to transurethral resection of prostate (TURP) during their lifetime. ${ }^{5}$ There are many modalities of treatment for BPO, which include drug therapies, endoscopic surgery like TURP among others and open prostatectomy. Monopolar Trans Urethral Resection of Prostate (M-TURP) is currently considered as gold standard. ${ }^{6,9}$

In M-TURP, the electrical current runs through the body from the active electrode (connected to the resectoscope loop) towards the large surfaced grounding path attached to the skin. In this electrical circuit, a non-conductive irrigation fluid (glycine, sorbitol, and mannitol) is mandatory to prevent dispersing of the electrical current. ${ }^{10} \mathrm{M}$-TURP has dominated surgical treatment of LUTS due to BPH for $>70$ years. ${ }^{11}$ Though, it has been considered to be the surgical "gold standard" for treatment of BPO, there is still potential for complications such as intraoperative bleeding, clot retention, and transurethral resection syndrome, and overall morbidity rate is reported at $11.1 \%{ }^{12-14}$

In the last decade, several novel procedures have been introduced for the treatment of BPO, and one of the novelest modifications could be the incorporation of bipolar technology to transurethral resection of the prostate using normal saline (NS) irrigation. Bipolar Trans Urethral Resection of Prostate (B-TURP) addresses the fundamental flaw of M-TURP because it can be performed in NS. Bipolar technology allows the electric current to complete without passing through the patient. ${ }^{5}$ Durable efficacies of TURP using bi- polar systems has been exhibited in a number of Randomized Controlled Trials (RCTs). Bipolar TURP has revealed promising results as shown by various studies. ${ }^{5}$

In this study, we have compared Monopolar and Bipolar TURP in terms of hospital Stay, resection time, resected tissue volume, changes in hemoglobin and sodium, blood transfusion required, complications like TUR syndrome, clot retention and hemorrhagic episodes with an objective to study the feasibility of bipolar TURP over M-TURP.

\section{METHODOLOGY}

An analytical study was done in all cases who had undergone TURP in Manipal Teaching Hospital in between August 2018 to August 2020 with an objective to compare post-operative results in between M-TURP and B-TURP techniques. Various clinico-demographic profiles [age, smoking, alcohol, comorbidities, preoperative status like prostate size, post void residual volume (PVRU), intravesical protrusion etc.] and intra and postoperative data [operative time, irrigation fluid required, resected tissue, pre and post-operative hemoglobin, sodium, packed cell volume (PCV), postoperative hemoglobin drop, blood transfusion required etc.] were collected and compared in between two commonly used techniques for TURP in our hospital; M-TURP and B-TURP.
All the patients operated during the study duration were included in the study. Patients whose data were incomplete in the records or whose records were untraceable due to various reasons were excluded from the study. After taking clearance from the Institutional Review Board (IRB) the records were collected from the departmental records and medical record department.

All the continuous data were presented in terms of mean and standard deviation and categorical data in terms of percentage. Comparison were done using student's t test for mean and chi square for percentages. The pre-operative and postoperative hemoglobin and sodium changes were compared using paired t test. $P$ value less than 0.05 was termed significant. Statistical analysis was done using SPSS 22.0 software.

\section{RESULTS}

During the study period, 86 patients had undergone TURP in our hospital operated by two urosurgeons. Out of these, only 73 patients fulfilled the inclusion criteria and rest were excluded either due to incomplete data or lost records. Out of 73 patients, 33 patients had undergone B-TURP and 40 Patients had undergone M-TURP.

On comparing various preoperative clinico-demographic factors like age, intake of alcohol, smoking, comorbidities, prostate size, PVRU, intravesical protrusion of prostate and biochemical parameters in between the two groups, we found no statistical significant difference suggesting similar distribution of cases in between the study population (Table 1.)

\begin{tabular}{|c|c|c|c|c|}
\hline S.N & PARAMETERS & M-TURP40) & B-TURP (33) & P value \\
\hline & Age & $71.75 \pm 6.953$ & $71.36 \pm 9.256$ & 0.839 \\
\hline & $\begin{array}{l}\text { Alcohol } \\
\text { Yes } \\
\text { No }\end{array}$ & $\begin{array}{l}7(9.6 \%) \\
33(45.2 \%)\end{array}$ & $\begin{array}{l}6(8.2 \%) \\
27(37 \%)\end{array}$ & 0.940 \\
\hline & $\begin{array}{l}\text { DM } \\
\text { Yes } \\
\text { No }\end{array}$ & $\begin{array}{l}5(6.8 \%) \\
35(47.9 \%)\end{array}$ & $\begin{array}{l}4(5.5 \%) \\
29(39.7 \%)\end{array}$ & 1.000 \\
\hline & $\begin{array}{l}\text { HTN } \\
\text { Yes } \\
\text { No }\end{array}$ & $\begin{array}{l}17(23.3 \%) \\
23(31.5 \%)\end{array}$ & $\begin{array}{l}14(19.2 \%) \\
19(26 \%)\end{array}$ & 0.995 \\
\hline & Prostate Size (gms) & $58.81 \pm 21.814$ & $66.26 \pm 29.633$ & 0.220 \\
\hline & $\begin{array}{l}\text { Intra Vesical } \\
\text { Protusion (mm) }\end{array}$ & $10.56 \pm 3.521$ & $11.76 \pm 3.744$ & 0.165 \\
\hline & PVRU (ml) & $83 \pm 51.684$ & $78.05 \pm 32.397$ & 0.634 \\
\hline & $\begin{array}{l}\text { Preopcatheterisation } \\
\text { Yes } \\
\text { No }\end{array}$ & $\begin{array}{l}5(6.8 \%) \\
35(47.9 \%)\end{array}$ & $\begin{array}{l}8(11 \%) \\
25(34.2 \%)\end{array}$ & 0.192 \\
\hline & $\begin{array}{l}\text { Anti-BPH Meds } \\
\text { Yes } \\
\text { No }\end{array}$ & $\begin{array}{l}16(21.9 \%) \\
24(32.9 \%)\end{array}$ & $\begin{array}{l}18(24.7 \%) \\
15(20.5 \%)\end{array}$ & 0.215 \\
\hline & Preop PCV & $36.13 \pm 3.849$ & $35.57 \pm 4.726$ & 0.577 \\
\hline & Preop Sodium & $139.62 \pm 139.625$ & $140.24 \pm 3.742$ & 0.472 \\
\hline & Preop Potassium & $4.03 \pm 0.504$ & $4.12 \pm 0.441$ & 0.441 \\
\hline & Urea & $27.47 \pm 11.794$ & $30.98 \pm 12.340$ & 0.219 \\
\hline & Creat & $0.97 \pm 0.209$ & $1.04 \pm .420$ & 0.395 \\
\hline
\end{tabular}

Total hospital stay was slightly lesser in B-TURP group although there was no statistical significant difference in between the two groups. The post-operative $\mathrm{Hb}$ in M-TURP group was $11.10 \pm 1.321$ and in B-TURP group was $12.24 \pm$ 1.225 and the difference was significant statistically $(P<0.001)$. Similarly, the difference in between post-operative PCV was 
statistically significant and lower in M-TURP group (33.22 \pm 4.002 Vs $36.25 \pm 3.751, p=0.001)$. The prostate tissue resected at the end of operation was significantly higher in B-TURP group ( $27.96 \pm 8.799$ vs $36.25 \pm 12.799, p=0.003)$. Similarly, the volume of irrigation fluid used introperatively was significantly higher in B-TURP Group (19.70 \pm 4.614 vs $24.30 \pm 4.462, P=<0.001)$. TUR syndrome was seen significantly higher in M-TURP group (6,8.2\%vs0, $0 \% ; \mathrm{P}=0.029)$. There was no significant difference in between resection time, post-operative sodium, post-operative hemorrhagic episodes, clot retention and blood transfusions (Table 2).

\begin{tabular}{|c|c|c|c|c|}
\hline S.N & PARAMETERS & M-TURP & B-TURP & $P$ value \\
\hline & Hospital Stay & $4.87 \pm 1.713$ & $4.30 \pm 1.531$ & 0.141 \\
\hline & Postoperative $\mathrm{Hb}$ & $11.10 \pm 1.321$ & $12.24 \pm 1.225$ & $<0.001^{*}$ \\
\hline & Postoperative PCV & $33.22 \pm 4.002$ & $36.25 \pm 3.751$ & $0.001^{*}$ \\
\hline & Postoperative Sodium & $138.58 \pm 6.242$ & $140.45 \pm 3.251$ & 0.104 \\
\hline & $\begin{array}{l}\text { Postop Hemorrhagic } \\
\text { episode } \\
\text { Yes } \\
\text { No }\end{array}$ & $\begin{array}{l}4(5.5 \%) \\
36(49.3 \%)\end{array}$ & $\begin{array}{l}0(0 \%) \\
33(45.2 \%)\end{array}$ & 0.122 \\
\hline & $\begin{array}{l}\text { Resected Tissue } \\
\text { weight (Gms) }\end{array}$ & $27.96 \pm 8.799$ & $36.25 \pm 12.799$ & $0.003 *$ \\
\hline & Resection Time (mins) & $60.63 \pm 16.467$ & $60.06 \pm 17.963$ & 0.889 \\
\hline & $\begin{array}{l}\text { Introp Irrigation } \\
\text { Volume }\end{array}$ & $19.70 \pm 4.614$ & $24.30 \pm 4.462$ & $<0.001^{*}$ \\
\hline & $\begin{array}{l}\text { Clot Retention } \\
\text { Yes } \\
\text { No }\end{array}$ & $\begin{array}{l}5(6.8 \%) \\
35(47.9 \%)\end{array}$ & $\begin{array}{l}1(1.4 \%) \\
32(43.8 \%)\end{array}$ & 0.212 \\
\hline & $\begin{array}{l}\text { BT } \\
\text { Yes } \\
\text { No }\end{array}$ & $\begin{array}{l}4(5.5 \%) \\
36(52.2 \%)\end{array}$ & $\begin{array}{l}0(0 \%) \\
33(45.2 \%)\end{array}$ & 0.122 \\
\hline & $\begin{array}{l}\text { TUR Syndrome } \\
\text { Yes } \\
\text { No }\end{array}$ & $\begin{array}{l}6(8.2 \%) \\
34(46.6 \%)\end{array}$ & $\begin{array}{l}0(0 \%) \\
33(45.2 \%)\end{array}$ & 0.029* \\
\hline
\end{tabular}

Table 3 shows pre and post-operative changes in hemoglobin and sodium in both the groups separately. Although the drop in hemoglobin was statistically significant in both the groups, the hemoglobin drop was slightly lesser in B-TURP group than in M-TURP group. The hemoglobin drop (mean difference in pre and post-operative $\mathrm{Hb}$ ) was 1.148 in M-TURP group and 0.181 in B-TURP Group.There were no statistical significant changes in pre and postoperative sodium in both the groups (Table3).

Table 3: Difference in between pre and post-operative
hemoglobin and Sodium in Monopolar and Bipolar TURP
\begin{tabular}{|l|l|l|l|l|}
\hline & Parameter & Preop Mean & Post Op Mean & P \\
\hline & M-TURP-Hb & $12.25 \pm 1.204$ & $11.10 \pm 1.322$ & $<0.001^{*}$ \\
\hline B-TURP HB & $12.42 \pm 1.219$ & $12.24 \pm 1.226$ & $0.018^{*}$ \\
\hline M-TURP-Na & $139.63 \pm 3.542$ & $138.58 \pm 6.242$ & 0.363 \\
\hline B-TURP-Na & $140.24 \pm 3.741$ & $140.45 \pm 3.251$ & 0.816 \\
\hline
\end{tabular}

\section{DISCUSSION}

B-TURP uses saline irrigation instead of glycine and hence protects against TUR syndrome which is one of the potential and dreaded complication of TURP. TUR syndrome is closely associated with capsule perforation during surgery and increased absorption of fluid during prolonged operations. In our series, TUR syndrome was seen in $6(8.2 \%)$ cases in $M$-TURP cases whereas there were no incidences of TUR syndrome in B-TURP cases ( $p=0.029)$. Tang $Y$ et al in their systematic review and meta-analysis found that out of 24 studies which had investigated TURP for TUR syndrome, none of the individual trials showed any significant difference between the bipolar and monopolar methods. However, a pooled analysis showed a significant difference (risk difference $0.02,95 \% \mathrm{Cl} 0.01-0.03 ; \mathrm{p}=0.0004$ ) which suggest incidences of TUR syndrome can be seen in B-TURP but in lesser proportion than M-TURP. ${ }^{15}$

Coagulation is always better and precise with minimal thermal injury to the surrounding tissue with a bipolar technique. ${ }^{16}$ Many studies have reported greater amount of blood loss with M-TURP. Bleeding and transfusion rates have greatly decreased over time. In our Study, the post-operative hemoglobin was significantly lesser in M-TURP group than in B-TURP (11.10 \pm 1.321 vs $12.24 \pm 1.225 ; \mathrm{P}<0.001)$. Similarly, the difference in between post-operative PCV was statistically significant and lower in M-TURP group (33.22 $\pm 4.002 \mathrm{Vs}$ $36.25 \pm 3.751, p=0.001)$. Although there were no significant difference in between post-operative hemorrhagic episodes, the incidences were nil in B-TURP group and 5.5\% (4 cases) in M-TURP group. None of the cases in B-TURPgroup required blood transfusion in comparison to four $(5.5 \%)$ cases of $\mathrm{M}$ TURP group, although the difference was not significant statistically. The post-operative drop in hemoglobin (difference between mean preoperative and post-operative hemoglobin) was statistically significant in both monopolar and B-TURP groups. However, the hemoglobin drop was slightly lesser in B-TURP group than in M-TURP group. The hemoglobin drop (mean difference in pre and postoperative $\mathrm{Hb}$ ) was 1.148 in M-TURP group and 0.181 in BTURP Group. Fagerstrom et al had found that the transfusion rates were significantly higher in M-TURP group than in BTURP group ( $11 \%$ vs $4 \%, p=0.01) .{ }^{16}$ Akman et al in their study noted that the decrease in mean hemoglobin concentration was greater in M-TURP group than in B-TURP group, though the difference was not statistically significant. ${ }^{17}$ Ho et al also noted a significant decrement in mean hemoglobin concentration $(1.8 \mathrm{mg} / \mathrm{dL})$ in monopolar group and no significant decrease in mean hemoglobin concentration in $\mathrm{B}$ TURP group ( $1.2 \mathrm{mg} / \mathrm{dL}$ ). ${ }^{18}$

The incidences of clot retention in overall TURP is around $2-5 \%$. $^{19}$ In our Series, clot retention was also seen in 5 cases of $\mathrm{M}$ TURP group (6.8\%) in comparison to single case $(1.4 \%)$ of BTURP group. Tang $Y$ et al in their systematic review and metaanalysis found that out of 13 studies which had investigated clot retention in M-TURP and B-TURP cases, a pooled analysis showed that clot retention was significantly higher in $\mathrm{M}$ TURP. (risk difference 0.04; 95\% Cl, 0.02-0.06; $\mathrm{P}<0.0001$ ). ${ }^{15}$

Total hospital stay in our study was slightly lesser in B-TURP group ( $4.30 \pm 1.531$ days) than in M-TURP group (4.87 \pm 1.713 days) though the difference was not statistically significant $(p=0.141)$. Studies have shown lesser mean duration of hospital stay in B-TURP than in M-TURP as in our study..$^{20}$ In M-TURP, the thermal energy is directed towards the prostatic tissue which creates a lot of resistance leading to severe increase in temperature. However, in cases of Bipolar-TURP, the current passes from active electrode to the adjacent return electrode via the target tissue, the tissue temperature is reduced. Furthermore, the saline irrigation medium in B-TURP is converted into a plasma field of ionized particles by energy which disrupts organic molecular bond 
of tissues. ${ }^{21}$ This can be the reason of minimal thermal injury and resulting inflammatory processes in B-TURP which leads to quick symptomatic recovery and less hospital stay.

Chen et al. reported decreases in mean postoperative serum sodium levels for the bipolar and M-TURP groups of 3.2 and $10.7 \mathrm{mmol} / \mathrm{L}$, respectively $(P<0.01) .{ }^{22}$ Akman et al also reported a significant decrease was detected in the mean sodium concentration of the monopolar group when compared to that of the bipolar group $(-2.82 \pm 5.8$ vs $1.30 \pm 3.8, p=0.03) .{ }^{17}$ In our study, there were no statistical significant mean changes in pre and post-operative sodium in both M-TURP and B-TURP groups (-1.05 vs 0.21).

The mean resection time in M-TURP group was $60.63 \pm$ 16.467 minutes and in Bipolar-TURP was $60.06 \pm 17.963$ minutes in our study without any statistical significant difference $(p=0.889)$. While most of the studies have reported similar operating time in between the two groups as in our study, fewer studies have also shown longer operating time in Bipolar-TURP. ${ }^{16,23,24}$

\section{RECOMMENDATION}

None

\section{REFERENCES}

1. Verhamme KMC, Dieleman JP, Bleumink GS, Van der Lei J, Sturkenboom MCJM. Incidence and prevalence of lower urinary tract symptoms suggestive of benign prostatic hyperplasia in primary care - The triumph project. Eur Urol. 2002 Oct 1;42(4):323-8. DOI:10. 1016/S0302-2838(02)00354-8

2. Yang EJ, Li H, Sun XB, Huang L, Wang L, Gong XX, et al. Bipolar versus monopolar transurethral resection of the prostate for benign prostatic hyperplasia: Safe in patients with high surgical risk. Sci Rep. 2016;6(Feb):1-5. DOI:10.1038/srep21494

3. Chapple C. Lower urinary tract symptoms suggestive of benign prostatic obstruction--Triumph: design and implementation. Eur Urol. 2001;39(suppl3):31-6. DOI:10.1159/000052565

4. Wei J, Calhoun E, Jacobsen S. Urologic diseases in America project: benign prostatic hyperplasia. J Urol. 2005;173:1256-61. DOI:10.1097/01.ju.0000155709.37840.fe

5. Giulianelli R, Albanesi L, Attisani F, Gentile BC, Vincenti G, Pisanti F, et al. Comparative randomized study on the efficaciousness of endoscopic bipolar prostate resection versus monopolar resection technique. 3-year follow-up. Arch Ital di Urol e Androl. 2013;85(2):86-91. DOI:10.4081/aiua.2013.2.86

6. Madersbacher S, Lackner J, Brossner C, Rohlich M, Stancik I, Willinger M. Reoperation, myocardial infarction and mortality after transurethral and open prostatectomy: a nation-wide, long-term analysis of 23,123 cases. Eur Urol. 2005;47:499-504. DOI:10.1016/ j.eururo.2004.12.010

7. Madersbacher S, Alivizatos G, Nordling J, Sanz C, Emberton M, de la RodetteJ. EAU 2004 guidelines on assessment, therapy and follow-up of men with lower urinary tract symptoms suggestive of benign prostatic obstruction (BPH guidelines). Eur Urol2. 2004;46(547-54). DOI:10.1016/j.eururo.2004.07.016

8. Madersbacher S, Marberger M. Is transurethral resection of the prostate stilljustified? BJU Int. 1999;83:227-37. DOI:10.1046/j.1464410x.1999.00908.x

9. Mebust W, Holtgrewe H, Cockett A, Peters P. Transurethral prostatectomy: immediate and postoperative complications: a cooperative study of 13 participating institutions evaluating 3,885 patients. JUrol. 1989;141:243-7. DOI:10.1016/S0022-5347(17)40731-2

\section{LIMITATION OF THE STUDY}

Since it is a retrospective study comparative study the power of study will be less than in prospective randomized study. Moreover, in our study, surgery was performed by two different urologists and the difference in technique amongst the surgeons could affected the outcomes in turn decreasing the power of study.

\section{ACKNOWLEDGEMENTS}

None

\section{CONFLICT OF INTEREST \\ None}

\section{FINANCIAL DISCLOSURE}

None
10. Michielsen DPJ, Coomans D, Peeters I, Braeckman JG. Conventional monopolar resection or bipolar resection in saline for the management of large (>60 g) benign prostatic hyperplasia: An evaluation of morbidity. Minim Invasive Ther Allied Technol. 2010;19(4):207-13. DOI:10.3109/13645706.2010.496963

11. Mayer EK, Kroeze SGC, Chopra S, Bottle A, Patel A. Examining the "gold standard": A comparative critical analysis of three consecutive decades of monopolar transurethral resection of the prostate (TURP) outcomes. BJU Int. 2012;110(11):1595-601. DOI:10.1111/j.1464410X.2012.11119.x

12. Burke N, Whelan J, Goeree L. Systematic review and meta- analysis of transurethral resection of the prostate versus minimally invasive procedures for the treatment of benign prostatic obstruction. Urology. Urology. 2010;75:1015-22. DOI:10.1016/j.urology. 2009.08.015

13. Ahyai S, Gilling P, Kaplan S. Meta-analysis of functional outcomes and complications following transurethral procedures for lower urinary tract symptoms resulting from benign prostatic enlargement. Eur Urol. 2010;58:384-97. DOI:10.1016/j.eururo.2010.06.005

14. Reich O, Gratzke C, Bachmann A. Morbidity, mortality and early outcome of transurethral resection of the prostate: a prospec- tive multicenter evaluation of 10,654 patients. J Urol. 2008;(180):246-9. DOI:10.1016/j.juro.2008.03.058

15. Tang Y, Li J, Pu C, Bai Y, Yuan H, Wei Q, Han P. Bipolar transurethral resection versus monopolar transurethral resection for benign prostatic hypertrophy: a systematic review and meta-analysis. J Endourol. 2014 Sep;28(9):1107-14. doi: 10.1089/end.2014.0188. DOI:10.1089/end.2014.0188

16. Fagerstrom T, Nyman CR, Hahn RG. Bipolar transurethral resection of the prostate causes less bleeding than the monopolar technique: a single-centre randomized trial of 202 patients. BJU Int. DOI:10.1111/ j.1464-410X.2009.09052.x

17. Akman T, Binbay M, Tekinarslan E, Tepeler A, Akcay M, Ozgor F, Ugurlu $M$, Muslumanoglu A. Effects of bipolar and monopolar transurethral resection of the prostate on urinary and erectile function: a prospective randomized comparative study. BJU Int. 2013 Jan;111(1):129-36. DOI:10.1111/j.1464-410X.2012.11266.x 
18. Ho HS, Yip SK, Lim KB, FookS, Foo KT, Cheng CW. A prospective randomized study comparing monopolar and bipolar transurethral resection of prostate using transurethral resection in saline (TURIS) system. EurUrol 2007; 52: 517-22. DOI:10.1016/j.eururo.2007.03.038

19. Rassweiler J, Teber D, Kuntz R, Hofmann R. Complications of transurethral resection of the prostate (TURP)-incidence, management, and prevention. EurUrol 2006;50:969-979. DOI:10.1016/ j.eururo. 2005.12.042

20. Sugihara T, Yasunaga $H$, Horiguchi $H$, Nakamura $M$, Nishimatsu $H$ Kume $\mathrm{H}$, et al. In-hospital outcomes and cost assessment between bipolar versus monopolar transurethral resection of the prostate. Journal of endourology. 2012; 26(8): 1053-1058 DOI:10.1089/end.2011.0592 DOI:10.1089/end.2011.0592

21. Pal D, Madduri VS and Bera M. Monopolar versus bipolar transurethral resection of prostate for benign prostatic hyperplasia: Operative outcomes and surgeon preferences, a real-world scenario. Urology Annals. 2016; 8(3): 291. DOI:10.4103/0974-7796.184900
22. Chen Q, Zhang L, Fan QL, Zhou J, Peng YB, Wang Z. Bipolar transurethral resection in saline vs traditional monopolar resection of the prostate: results of a randomized trial with a 2-year follow-up. BJU Int. 2010 Nov;106(9):1339-43. DOI:10.1111/j.1464-410X.2010.09401.x

23. Michielsen DP, Debacker T, De Boe $V$ et al. Bipolar transurethral resection in saline-an alternative surgical treatment for bladder outlet obstruction? J Urol 2007; 178: 2035-9 DOI:10.1016 /j.juro.2007.07.038

24. Fagerström T, Nyman CR, Hahn RG. Complications and clinical outcome 18 months after bipolar and monopolar transurethral resection of the prostate. J Endourol 2011; 25: 1043-9 DOI:10.1089/end.2010.0714 